\title{
Into the Seed: Auxin Controls Seed Development and Grain Yield
}

\author{
Jinshan Cao, Guoji Li, Dejie Qu, Xia Li and Youning Wang * \\ State Key Laboratory of Agricultural Microbiology, College of Plant Science and Technology, Huazhong \\ Agricultural University, Wuhan 430070, China; jinshancao@webmail.hzau.edu.cn (J.C.); \\ lgj2389868525@163.com (G.L.); dejiequ@163.com (D.Q.); xli@mail.hzau.edu.cn (X.L.) \\ * Correspondence: youningwang@mail.hzau.edu.cn; Tel.: +86-027-8728-2130; Fax: +86-027-8728-2139
}

Received: 15 January 2020; Accepted: 25 February 2020; Published: 28 February 2020

\begin{abstract}
Seed development, which involves mainly the embryo, endosperm and integuments, is regulated by different signaling pathways, leading to various changes in seed size or seed weight. Therefore, uncovering the genetic and molecular mechanisms of seed development has great potential for improving crop yields. The phytohormone auxin is a key regulator required for modulating different cellular processes involved in seed development. Here, we provide a comprehensive review of the role of auxin biosynthesis, transport, signaling, conjugation, and catabolism during seed development. More importantly, we not only summarize the research progress on the genetic and molecular regulation of seed development mediated by auxin but also discuss the potential of manipulating auxin metabolism and its signaling pathway for improving crop seed weight.
\end{abstract}

Keywords: auxin; auxin metabolism; auxin signaling; seed development; seed weight; seed yield

\section{Introduction}

With the exponential increase in the global population, food supplies have become a serious issue that cannot be ignored. The critical question is how to sustain food production for the planet but without any additional increases in the use of available arable land. Importantly, the optimization and utilization of the main factors influencing crop yields have great potential for increasing yields in the limited areas with soil. Among these factors, seed weight is one of the most important three factors determining grain production of cereal crops. Accordingly, bulk seed weight is used as an indicator of average seed size [1], and this morphophysiological trait contributes to seed development in domesticated plant species [2,3].

Seed development is coordinated by the growth of the embryo, endosperm and the maternal ovule in both monocots and dicots, in which the maternal ovule develops into the integuments and ultimately leads to the generation of the seed coat $[2,4,5]$. In many dicots, both integument (seed coat) and embryo development play determinative roles in seed size. Except for supplying nutrients for embryo development, most of the endosperm volume is replaced by the embryo [6]. In contrast, in monocots and some dicots, the endosperm is retained and contributes to the volume of the mature seed [2]. Interestingly, the growth of the seed is not primarily related to the subsequent growth of the embryo but rather to the initial growth of the endosperm [2]. In addition, in some dicot species, such as those of Arabidopsis and Brassica, the silique wall has been confirmed to be the main source of nutrition in developing seeds, providing photosynthates for seed growth [7-10]. Various cellular processes also influence seed development. Endosperm formation occurs initially via nuclear divisions and subsequent cellularization, and the endosperm grows much more rapidly than the embryo. Due to the retaining of a large endosperm, the process of endosperm cellularization is also involved in seed size control [11]. 
During the past century, seed or grain size has been considered an important indicator for breeders; however, only within the past decade have the molecular regulators mediating seed size formation been started to be identified in plants, particularly in model plant species, such as Arabidopsis [5,11-19]. Several signaling pathways that determine seed size by affecting the growth of maternal tissue and/or endosperm have been defined, including the IKU (HAIKU) pathway, the ubiquitin-proteasome pathway, G-protein signaling and multiple phytohormone signaling pathways $[5,13,17,18,20-31]$. Thus, seed development is controlled by spatially and temporally integrated molecular regulatory networks coupled with the spatial-temporal distribution of multiple types of phytohormones.

Among these hormones, auxin is a key component in seed development and seed weight. The role of auxin in seed development was noticed approximately 80 years ago [32], and compelling evidence has demonstrated that auxin regulation of seed development is concentration dependent. The spatial-temporal distribution of active auxin is dynamically modulated by auxin biosynthesis, auxin polar transport and signal transduction, auxin conjugation, and auxin catabolism, all of which maintain auxin at optimal levels for seed development. In this review, we provide an extensive overview of the role of auxin during seed development (Table 1, Figure 1) and discuss the potential significance in increasing crop yields.

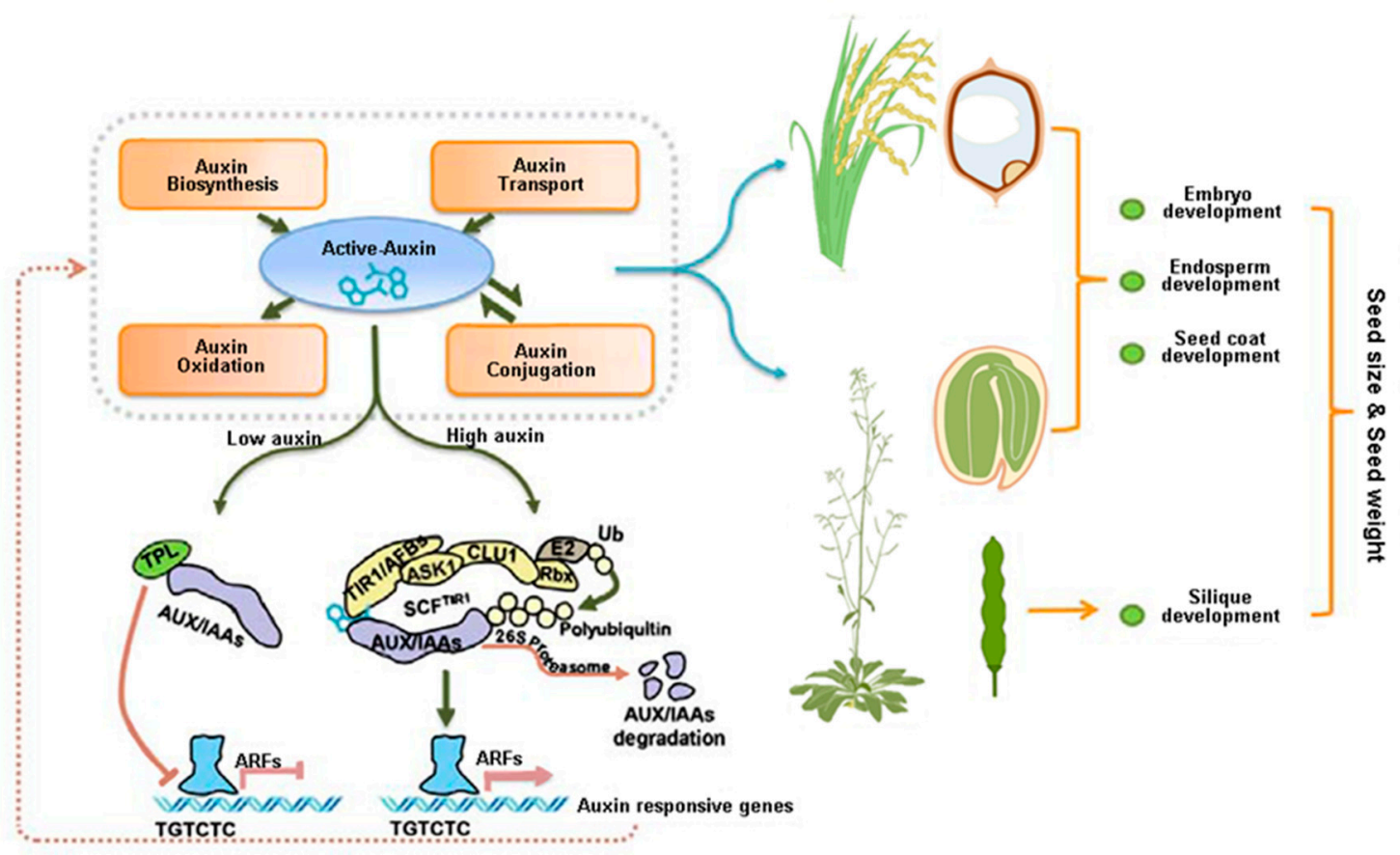

Figure 1. The developmental processes that are controlled by auxin and its potential impacts on seed size and weight. Active auxin, influenced by auxin biosynthesis, oxidation, conjugation, and transport, initiates auxin signaling pathway, in turn, which also have a potential feedback loop for maintaining the fine cellular auxin concentration. In both monocotyledon and dicotyledon plants, auxin has been found to be involved in regulating the development of embryo, endosperm and seed coat, which have the potential role in determining the seed size and seed weight of plants. Recent studies have confirmed that silique development also has the impact on seed development. 
Table 1. Identified genes involved in the auxin control of seed development in plants.

\begin{tabular}{|c|c|c|c|c|c|c|c|}
\hline $\begin{array}{l}\text { Botanical } \\
\text { Classification }\end{array}$ & Species & $\begin{array}{l}\text { Accession } \\
\text { Number }\end{array}$ & Gene Name & Protein Category & $\begin{array}{l}\text { Impact on Seed } \\
\text { Development }\end{array}$ & $\begin{array}{l}\text { Possible Role for } \\
\text { Auxin }\end{array}$ & References \\
\hline \multirow[t]{8}{*}{ Monocotyledon } & Maize & GRMZM2G091819 & $\mathrm{ZmYuc1}$ & Flavin monooxygenases & $\begin{array}{l}\text { Endosperm } \\
\text { development }\end{array}$ & $\begin{array}{l}\text { Involved in auxin } \\
\text { biosynthesis }\end{array}$ & Bernardi et al., 2012 \\
\hline & Rice & Os06g0623700 & TGW6 & $\begin{array}{l}\text { Indole-3-acetic acid } \\
\text { IAA-glucose hydrolase }\end{array}$ & $\begin{array}{l}\text { Cell number and grain } \\
\text { length, Seed weight }\end{array}$ & $\begin{array}{l}\text { Controls the supply of } \\
\text { IAA }\end{array}$ & Ishimaru et al., 2013 \\
\hline & Rice & Os02g07430 & MADS29 & $\begin{array}{l}\text { MADS-box } \\
\text { transcription factor }\end{array}$ & $\begin{array}{l}\text { Endosperm } \\
\text { development }\end{array}$ & Induced by auxin & Yin and Xue, 2012 \\
\hline & Rice & Os03g0175800 & $B G 1$ & $\begin{array}{l}\text { Novel plasma } \\
\text { membrane-associated } \\
\text { protein }\end{array}$ & Grain size & $\begin{array}{l}\text { Regulates auxin } \\
\text { transport }\end{array}$ & Liu et al., 2015 \\
\hline & Rice & Os05g32270 & SMOS1 & AP2 transcription factor & Seed size & $\begin{array}{l}\text { Induced by exogenous } \\
\text { auxin treatment, } \\
\text { interacts with ARF }\end{array}$ & Aya et al., 2014 \\
\hline & Rice & Os07g0603700 & OsGE/CYP78B5 & $\begin{array}{l}\text { Cytochrome P450 } \\
\text { enzyme }\end{array}$ & Embryo development & $\begin{array}{l}\text { Regulates auxin } \\
\text { responsive gene }\end{array}$ & Chen et al., 2014 \\
\hline & Rice & Os03g62500 & OsSK41 & $\begin{array}{l}\text { GLYCOGEN } \\
\text { SYNTHASE KINASE } \\
\text { 3/SHAGGY-like family }\end{array}$ & $\begin{array}{l}\text { Grain length, Grain } \\
\text { weight }\end{array}$ & Interacts with OsARF4 & Hu et al., 2018 \\
\hline & Rice & Os06g03710 & $S M O S 2 / D L T$ & $\begin{array}{l}\text { GRAS transcription } \\
\text { factor }\end{array}$ & Seed size & $\begin{array}{l}\text { Involved in auxin-BR } \\
\text { signaling crosstalk }\end{array}$ & Hirano et al., 2017 \\
\hline \multirow[t]{4}{*}{ Dicotyledon } & Pea & JN990989 & PsTAR2 & $\begin{array}{l}\text { Trytophan } \\
\text { aminotransferase } \\
\text { related protein }\end{array}$ & $\begin{array}{l}\text { Reduced starch } \\
\text { content, Seed size }\end{array}$ & $\begin{array}{l}\text { Involved in auxin } \\
\text { biosynthesis }\end{array}$ & $\begin{array}{l}\text { Tivendale et al., 2012; } \\
\text { McAdam et al., } 2017\end{array}$ \\
\hline & Rape & BnaA09G55530D & ВиаА9.СҮР78А9 & $\begin{array}{l}\text { Cytochrome P450 } \\
\text { enzyme }\end{array}$ & $\begin{array}{l}\text { Silique length, Seed } \\
\text { size }\end{array}$ & $\begin{array}{l}\text { Influences auxin } \\
\text { metabolism or auxin } \\
\text { biosynthesis }\end{array}$ & Shi et al., 2019 \\
\hline & Arabidopsis & $\begin{array}{l}\text { At4G32540, } \\
\text { At5G11320, } \\
\text { At1G48910, } \\
\text { At1G21430 }\end{array}$ & $\begin{array}{l}\text { YUC1, YUC4, } \\
\text { YUC10, YUC11 }\end{array}$ & Flavin monooxygenases & $\begin{array}{l}\text { Embryogenesis and } \\
\text { post-embryonic organ } \\
\text { formation }\end{array}$ & $\begin{array}{l}\text { Involved in auxin } \\
\text { biosynthesis }\end{array}$ & Cheng et al., 2007 \\
\hline & Arabidopsis & At1G28300 & LEC2 & $\begin{array}{l}\mathrm{AP} 2 / \mathrm{B} 3-\text { like } \\
\text { transcriptional factor } \\
\text { family protein }\end{array}$ & Embryo development & $\begin{array}{l}\text { Regulates the supply } \\
\text { of auxin }\end{array}$ & $\begin{array}{l}\text { Stone et al., 2008; } \\
\text { Wójcikowska et al., } 2013\end{array}$ \\
\hline
\end{tabular}


Table 1. Cont.

\begin{tabular}{|c|c|c|c|c|c|c|c|}
\hline $\begin{array}{l}\text { Botanical } \\
\text { Classification }\end{array}$ & Species & $\begin{array}{l}\text { Accession } \\
\text { Number }\end{array}$ & Gene Name & Protein Category & $\begin{array}{l}\text { Impact on Seed } \\
\text { Development }\end{array}$ & $\begin{array}{l}\text { Possible Role for } \\
\text { Auxin }\end{array}$ & References \\
\hline \multirow[t]{12}{*}{ Dicotyledon } & Arabidopsis & At1G51950 & $I A A 18$ & $\begin{array}{l}\text { Auxin-responsive } \\
\text { protein }\end{array}$ & $\begin{array}{l}\text { Cotyledon placement, } \\
\text { Embryo growth }\end{array}$ & $\begin{array}{l}\text { Interferes with auxin } \\
\text { transport }\end{array}$ & Ploense et al., 2009 \\
\hline & Arabidopsis & $\begin{array}{l}\text { At2G38120, } \\
\text { At5G01240, } \\
\text { At2G21050 }\end{array}$ & $\begin{array}{l}\text { AUX1, LAX1, } \\
\text { LAX2 }\end{array}$ & $\begin{array}{l}\text { Transmembrane amino } \\
\text { acid transporter family } \\
\text { proteins }\end{array}$ & $\begin{array}{l}\text { Endosperm } \\
\text { development, Radicle } \\
\text { apex growth }\end{array}$ & $\begin{array}{l}\text { Regulates auxin } \\
\text { transport }\end{array}$ & $\begin{array}{l}\text { Robert et al., 2015; } \\
\text { Ugartechea-Chirino et } \\
\text { al., } 2010\end{array}$ \\
\hline & Arabidopsis & At5G60440 & AGL62 & $\begin{array}{l}\text { MADS-box } \\
\text { transcription factor }\end{array}$ & Embryo development & $\begin{array}{l}\text { Involved in auxin } \\
\text { transport }\end{array}$ & Figueiredo et al., 2015 \\
\hline & Arabidopsis & $\begin{array}{l}\text { At1G73590, } \\
\text { At1G70940, } \\
\text { At2G01420, } \\
\text { At1G23080 }\end{array}$ & $\begin{array}{l}\text { PIN1, PIN3, PIN4, } \\
\text { PIN7 }\end{array}$ & PIN-FORMED proteins & Embryo development & $\begin{array}{l}\text { Regulates auxin } \\
\text { transport }\end{array}$ & Friml et al., 2003 \\
\hline & $\begin{array}{l}\text { Medicago } \\
\text { truncatula }\end{array}$ & Medtr $2 g 014060$ & $D A S H$ & DOF transcription factor & $\begin{array}{l}\text { Endosperm } \\
\text { development }\end{array}$ & Affects auxin export & Noguero et al., 2015 \\
\hline & Arabidopsis & At5G16560 & KANADI & $\begin{array}{l}\text { Homeodomain-like } \\
\text { superfamily protein }\end{array}$ & $\begin{array}{l}\text { Integument } \\
\text { development }\end{array}$ & Regulated by auxin & Kelley et al., 2012 \\
\hline & Arabidopsis & At3G62980 & TIR1 & F-box protein & Embryo development & Response to auxin & Dharmasiri et al., 2005 \\
\hline & Arabidopsis & $\begin{array}{l}\text { At4G03190, } \\
\text { At3G26810, } \\
\text { At1G12820 }\end{array}$ & AFB1, AFB2, AFB3 & F-box proteins & Embryo development & Response to auxin & Dharmasiri et al., 2005 \\
\hline & Arabidopsis & At5G62000 & $A R F 2$ & $\begin{array}{l}\text { AUXIN RESPONSE } \\
\text { FACTOR (ARF) } \\
\text { transcription factor }\end{array}$ & $\begin{array}{l}\text { Integument } \\
\text { development, Seed } \\
\text { size }\end{array}$ & Response to auxin & Schruff et al., 2006 \\
\hline & Arabidopsis & At2G33860 & ETT/ARF3 & $\begin{array}{l}\text { AUXIN RESPONSE } \\
\text { FACTOR (ARF) } \\
\text { transcription factor }\end{array}$ & $\begin{array}{l}\text { Integument } \\
\text { development }\end{array}$ & Response to auxin & Kelley et al., 2012 \\
\hline & Arabidopsis & At1G04550 & BDL/IAA12 & $\begin{array}{l}\text { AUXIN/INDOLE-3-ACET } \\
\text { ACID (AUX/IAA) } \\
\text { transcriptional } \\
\text { repressors }\end{array}$ & Embryo development & Response to auxin & Hamann et al., 2002 \\
\hline & Arabidopsis & At1G19850 & MONOPTEROS/AR & $\begin{array}{l}\text { AUXIN RESPONSE } \\
\text { 5FACTOR (ARF) } \\
\text { transcription factor }\end{array}$ & Embryo development & Response to auxin & $\begin{array}{l}\text { Berleth and Jürgens, } \\
1993\end{array}$ \\
\hline
\end{tabular}


Table 1. Cont.

\begin{tabular}{|c|c|c|c|c|c|c|c|}
\hline $\begin{array}{l}\text { Botanical } \\
\text { Classification }\end{array}$ & Species & $\begin{array}{l}\text { Accession } \\
\text { Number }\end{array}$ & Gene Name & Protein Category & $\begin{array}{l}\text { Impact on Seed } \\
\text { Development }\end{array}$ & $\begin{array}{l}\text { Possible Role for } \\
\text { Auxin }\end{array}$ & References \\
\hline \multirow[t]{3}{*}{ Dicotyledon } & Arabidopsis & At3G22886 & MIR167A & microRNA & $\begin{array}{l}\text { Ovule development, } \\
\text { Embryos growth, } \\
\text { Endosperms } \\
\text { development }\end{array}$ & Response to auxin & $\begin{array}{l}\text { Yao et al., 2019; Na et al., } \\
2019\end{array}$ \\
\hline & Rape & BnaA09G55580D & ARF18 & $\begin{array}{l}\text { AUXIN RESPONSE } \\
\text { FACTOR (ARF) } \\
\text { transcription factor }\end{array}$ & Silique development & Response to auxin & Liu et al., 2015 \\
\hline & Tobacco & LOC107800718 & NtTTG2 & $\begin{array}{l}\text { WRKY transcription } \\
\text { factor }\end{array}$ & $\begin{array}{l}\text { Seed production, Seed } \\
\text { development }\end{array}$ & $\begin{array}{l}\text { Impacts the nuclear } \\
\text { import of NtARF8 }\end{array}$ & $\begin{array}{l}\text { Zhu et al., 2013; Ge et al., } \\
2016\end{array}$ \\
\hline
\end{tabular}




\section{Auxin Levels Influence Seed Development}

It is well known that auxin regulates various aspects of seed development, including the development of the embryo, endosperm and seed coat, after fertilization. In plants, auxin accumulation and distribution are varied during seed development. It has been shown that, in maize, the concentration of free indole-3-acetic acid (IAA) quickly increases between 8 and 28 days after pollination (DAP), with a decline at 20 DAP [33-35]. In Arabidopsis, auxin accumulates in immature seeds at the heart, torpedo, and cotyledon stages, specifically at the ends of hypophysis and cotyledon primordia during somatic embryo development [36]. The endogenous IAA levels in the spikelets also increased after pollination and during subsequent fruit development, and this increase is positively correlated with IAA synthesis in the ovary of rice [37]. There is evidence to show that OsGE/CYP78B5 may regulate embryo size by maintaining normal levels of IAA in rice [38]. In line with these results, auxin has been found to be involved in regulating endosperm proliferation in maize [33,39]. Recent studies have confirmed that auxin production also influences endosperm proliferation rates and cellularization during seed development in Arabidopsis [40,41] Interestingly, auxin synthesized in the developing endosperm can be exported into the integuments and is necessary for seed coat development $[40,42]$. These observations support that auxin is required for regulating embryo, endosperm, and seed coat development.

The main source of auxin originates from its biosynthesis. To date, five IAA biosynthetic pathways have been proposed, including four inter-connected Trp-dependent IAA biosynthetic pathways and one Trp-independent pathway [35,43]. Among these pathways, the indole-3-pyruvic acid (IPA) pathway has been found to be the main IAA biosynthesis pathway in Arabidopsis, in which both TAA (tryptophan amino transferases) and YUCCA (YUC) function as main components that modulate this pathway [44-46]. Previous studies have shown that TAA- and YUC-related genes participate in regulating seed development. In Arabidopsis, YUC1, YUC4, YUC10, and YUC11 redundantly regulate embryonic development by modulating auxin biosynthesis at the globular stage [47]. In pea, tar2-1, a loss-of-function mutant of PSTAR2 (TRYPTOPHAN AMINOTRANSFERASE-RELATED 2), presents reduced embryo fresh weight (FW), leading to the formation of a small seed with a reduced starch content and a wrinkled phenotype [43,48]. Interestingly, some evidence shows that maternally produced auxin in the integuments is required for early embryo development of Arabidopsis [49]. Auxin biosynthesis is also required for endosperm development. It has been reported that the MADS-box transcription factor AGL62 (AGAMOUS-LIKE 62) contribute to endosperm initiation through repressing auxin biosynthesis genes expression [40]. A loss of mutation in the Defective Endosperm 18/ZmYuc1 gene (DE18/ZmYuc1) is associated with IAA deficiency, leading to defective proliferation of the endosperm and a small-seed phenotype [33,50]. Additionally, it is interesting to note that auxin also regulates silique development. Overexpression of BnaA9.CYP78A9, which encodes a P450 monooxygenase, induces a significant increase in auxin in developing siliques, stimulating the elongation of siliques in Brassica napus [51].

Although auxin has an important role in regulating seed development, the regulatory mechanisms that underlie auxin-modulated auxin synthesis and accumulation have received little research attention. Until now, only a few findings have given clues about the regulatory mechanism governing auxin. It has been found that, to modulate seed development, the key genes involved in auxin biosynthesis might be directly regulated by transcription factors. For example, YUC4 has been confirmed to be a direct target of LEC2 during somatic embryogenesis [52,53]. The fact that one of MADS-box transcription factors, MADS29, a key regulator in endosperm development, is also induced by auxin in rice suggests alterations in auxin during endosperm development [54]. These data suggest that auxin biosynthesis might undergo transcriptional regulation during seed development.

Auxin also has the capability of regulating apomictic seed formation (apomixis), which has high economic potential for maintaining or utilizing heterosis by permitting the formation of seeds without fertilization [55]. It has long been noted that exogenous applications of auxin can induce parthenocarpic fruit development by stimulating the growth of ovaries in plant species such as tomato, petunia, 
salpiglossis, and pepper [32]. In other species, exogenous applications of synthesized auxin (2,4-D) can also promote parthenocarpic development of rice ovaries $[37,56]$ and stimulate autonomous endosperm proliferation and seed coat development in maize and Arabidopsis [34,40,42]. The phenotypic effects of the TAR2 mutation could be partially rescued by 2,4-D applications to mature pea leaves [48]. These results indicate the potential role of auxin in crop breeding in which heterosis is maintained via engineered apomixis $[55,57,58]$

\section{Auxin Transport-Mediated Seed Development}

Auxin transport is responsible for the auxin redistribution and gradient in different plant tissues in response to developmental signals or environmental stimuli. PIN-FORMED (PIN) efflux transporters and AUXIN/LIKE AUXIN (AUX/LAX family) auxin influx carriers (AUX/LAX1 family) are responsible for auxin distribution in plant cells [59]. Extensive evidence has shown that auxin efflux and influx mediate the active transport of auxin during seed development.

Auxin-dependent cell specification involved in embryo development requires the balance of auxin transport modulated by both influx and efflux mechanisms [60]. It has been reported that polar auxin transport is correlated with embryonic differentiation and definition [39]. Moreover, it has been assumed that PIN-mediated auxin efflux is responsible for seed development, which is also supported by the results of expression patterns and morphological analyses. In Arabidopsis, there are 8 PIN-FORMED (PIN) genes that encode auxin efflux transporters and control polar auxin transport in plants [9,35,61], among which PIN1, PIN3, PIN4, and PIN7 are expressed in the embryo [62]. Phenotypic analysis showed that pin 1 mutants display defects at the basal embryo pole, while the pin 7 mutant appears to have defects in the stereotypical patterning of early embryogenesis [62]. Moreover, the quadruple mutant pin 1 pin 3 pin 4 pin 7 displays severe defects in proembryo establishment, indicating functional redundancy among different PIN proteins [62]. Additional studies have confirmed that an apical-basal auxin gradient regulated by PIN1 and PIN7 appears to function in specifying the apical embryo structures and subsequently reorganizing the auxin gradient for specification of the basal root pole $[62,63]$. In line with this result, previous studies in wheat support the notion that heterogeneous auxin distribution has a conserved role in modulating embryonic pattern formation [64,65]. In addition, the expression patterns of homologous ZmPIN genes appear to be different during kernel development. The expression of three ZmPIN1 genes is induced after double fertilization, and their associated proteins also colocalize in developing embryos [39]. In accordance with these results, the expression of ZmPIN5c is upregulated from 3 to 12 DAP during kernel development [66]. Although there is the possibility for functional redundancy among PIN proteins, these findings also provide strong evidence for the conserved role of auxin polar transport mediated by PIN proteins during seed development. Accordingly, treatment of kernels with the auxin transport inhibitor N-1-naphthylphthalamic acid (NPA) abolishes the auxin gradient inside the embryo and the relatively high accumulation of auxin in the embryo root during the morphogenetic phase, leading to abnormal embryonic root development [39]. At the early stages of endosperm development, auxin appears to highly accumulate at the endosperm margin but is relatively low in the center of the endosperm [35], which is disrupted by the addition of NPA, resulting in a multilayered aleurone [39]. Moreover, Medicago truncatula DASH, encoding an endosperm-specific DOF transcription factor, is also identified to positively regulate endosperm development by affecting auxin export [67].

Studying the role of PIN proteins (auxin efflux transporters) during seed development has been gaining increased amounts of attention. By contrast, the role of auxin influx carriers in seed development remains elusive. It has been well documented that AUX1 (AUXIN RESISTANT 1) and its homologues LAX1, LAX2, and LAX3 (LIKE AUXIN RESISTANT) participate in auxin cellular influx [68-70]. Members of the AUX1/LAX family have been found to be associated with the establishment of cell patterns in the apex of embryonic roots [71]. A convincing example comes from phenotypic analysis of a double mutant, aux1 lax, which has a larger radicle root cap than does the wild type [71]. In contrast, the embryonic phenotype of aux1 lax1 lax2 lax3 quadruple mutants exhibits an extreme disorganization 
of the radicle apex [71]. Until recently, it has been demonstrated that AUX1, LAX1, and LAX2 are involved in the formation of the shoot and root poles in both the microspore-derived embryos of Brassica napus and the zygotic embryos of Arabidopsis thaliana [60]. These results provide direct evidence that the auxin importers AUX1/LAX are also regulators of embryonic root formation.

\section{The Auxin Signaling Pathway Is Involved in Seed Development}

The fluctuation of auxin accumulation can trigger or deactivate the auxin signaling pathway, which can mediate cellular and plant responses. In the presence of auxin, the degradation of Aux/IAA proteins is promoted after auxin is perceived by the receptor complex SCFTIR1/AFB in the nucleus, leading to the derepression of auxin response factors (ARFs) and the initiation of the auxin response [72-75]. The F box proteins TIR1 (Transport Inhibitor Response 1), AFB1, AFB2, and AFB3 assemble into SCF complexes and function as auxin receptors [74]. ARFs are transcription factors that have the capability of recognizing AUXIN RESPONSE ELEMENTs (AuxREs) within the promoter regions of downstream genes and regulating their expression [73,76]. Once the expression of ARFs appears to be de-repressed or activated, a subset of primary auxin response genes, such as GH3 (Gretchen Hagen 3 ) and SAUR (Small auxin-up RNA), are activated or de-repressed [77]. As a result, this system functions to induce extremely rapid changes in response to auxin. In turn, the active auxin level in cells is regulated to match the needs of plant development.

Extensive studies have shown that the core components of the auxin signaling pathway function in the seed development of plants, especially during the development of embryos. The spatial pattern of auxin responses appears to be easily visualized by monitoring the synthetic auxin-responsive promoter DR5, which also allows detection of auxin redistribution [62]. The use of DR5rev::GFP reveals the dynamic gradients of auxin accumulation and response during early embryogenesis in Arabidopsis. Immediately after the division of the zygotes, the accumulation and response of auxin become detectable in the apical cell and then increase in the developing proembryo, with a weak signal in the suspensor [62]. In Arabidopsis, all auxin receptor genes are expressed during embryogenesis, among which the TIR1 and AFB1 genes are moderately expressed, whereas AFB2 and AFB3 are expressed at relatively high levels [74]. Compared with the normal embryos of tir1-1, afb2-1, and afb3-1 single mutants, 48\% of tir1-1 afb2-1 afb3-1 embryos appear to have defects in embryogenesis [74]. Previous studies have also shown that Aux/IAA proteins might be involved in seed development. The phenotype of the Arabidopsis gain-of-function mutant BODENLOSS (BDL), whose mutated gene encodes IAA12, is similar to that of the $m p$ mutant and strongly resembles the phenotype of tir 1 afb triple and quadruple mutant seedlings [78]. In addition, a previous study showed that AtIAA18 is expressed in the apical domain of globular embryos [79]. Gain-of-function iaa18-1 mutations maintain the stability of the Aux/IAA protein IAA18, leading to the formation of aberrant cotyledon placement in embryos of Arabidopsis [79]. To date, the roles of ARF transcription factors in embryo development have been well documented. Mutants of ARF2, ARF3, and ARF5/MONOPTEROS (MP) appear to have defects in Arabidopsis embryonic development, in which the monopteros mutant fails to initiate root meristem during early embryogenesis [15,78,80-82]. In Arabidopsis, ARF6 and ARF8 have been confirmed to be directly targeted by microRNA167 (miR167) in regulating plant reproduction $[83,84]$. It has been demonstrated that MIR167A, acting as a maternal gene, modulates embryonic and endosperm development mainly by targeting $A R F 6$ and $A R F 8$ [85]. In addition, despite a lack of knowledge about the functional confirmation of $Z m A R F$ genes, seven $Z m A R F$ genes appear to exhibit constitutive expression patterns in developing embryos [86].

Moreover, auxin is also involved in other processes of seed development. By utilizing a DR5v2::VENUS reporter, researchers have shown that auxin signaling is active in seed coat development [42]. ARF2 regulates seed size by inhibiting integument cell proliferation during ovule development $[15,82]$. Furthermore, ARF3/ETTIN (ETT) physically interacts with KANADI (KAN) transcription factors to regulate integument development in Arabidopsis, which is required for embryo, leaf, carpel, and ovule development [87]. The alterations associated with the phenotype of ett mutants appear to be similar to 
those of the mutants of ABERRANT TESTA SHAPE (ATS or KAN4), which form abnormal seeds bearing congenital fusion of the inner and outer integuments [87]. In tobacco, the expression of ARF genes is modulated by NtTTG2 (TRANSPARENT TESTA GLABRA 2), which is required for the development of seeds [88]. Additional studies have shown that the expression of NtTTG2 can induced by a synthetic auxin, 1-naphthaleneacetic acid (NAA), and that the function of NtTTG2 in seed production is also associated with NtARF8 [89]. In addition, ARF18 regulates silique development by accelerating cell expansion in the silique walls of Brassica napus L., leading to changes in seed development [10].

\section{Auxin Homeostasis-Mediated Regulation of Seed Development}

It is well known that almost all aspects of the plant life cycle, including seed development, appear to be modulated by the concentration gradients of auxin, which are determined by the maintenance of the optimal active auxin level in different tissues and organs at different developmental stages [90-92]. The dynamic regulation of auxin homeostasis not only depends on auxin biosynthesis and polar transport but also modulates auxin conjugation (mainly to amino acids and sugars) and catabolism (mainly oxidation) [93-95]. Together with the above-mentioned data, there is a significant understanding of the contributions of auxin biosynthesis, polar transport, and signaling during seed development. However, although auxin conjugation and catabolism are well-known processes that take part in the dynamic regulation of auxin homeostasis, their roles in seed development remain less known due to a lack of identification of genes that are involved in auxin conjugation or catabolism and that modulate seed development. It is evident that the lack of suitable tools for quantifying and visualizing auxin metabolites at the cellular or tissue level hinders functional analyses of the roles of auxin conjugation and catabolism in seed development. Although many genes involved in auxin biosynthesis, transport, and signaling pathways have also been identified to be involved in the regulation of seed development, few genes modulate seed development by maintaining auxin homeostasis. However, indirect evidence suggests that auxin homeostasis is probably involved in seed development. For example, some signaling components involved in auxin signaling or conjugation, including genes encoding AUX/IAA proteins, ARFs, auxin-responsive SAUR family proteins and GH3 proteins, appear to be upregulated by MADS29, which is required for endosperm development in rice [54]. In line with this fact, in the defective endosperm 18 (de18) mutant of maize, the expression of key factors acting on the pathways controlling auxin homeostasis, such as GH3 genes, a DAO-like (DIOXYGENASE FOR AUXIN OXIDATION-like) gene and 2 indole-3-acetate beta-glucosyltransferase genes, is significantly downregulated [50]. In addition, based on the analysis of differentially expressed genes the NIL (SW) (ARF18) and R1 lines (ARF18 ${ }^{+}$) of Brassica napus, it is of interest to see that additional early auxin-responsive genes, such as $A u x / I A A, S A U R$, and GH3 genes, are differentially expressed [10].

At present, only TGW6 (THOUSAND-GRAIN WEIGHT 6), which encodes a protein that exerts indole-3-acetic acid (IAA)-glucose hydrolase activity and controls IAA supplies, has been confirmed to be a negative regulator of grain weight and to increase rice yields [96]. Additional studies have shown that TGW6 affects the expression of many auxin-responsive genes, suggesting that TGW6 might be involved in regulating seed development in rice by modulating auxin homeostasis [96]. However, direct evidence to confirm the role of TGW6 at the cellular level of seed development and the mechanism by which TGW6 regulates auxin homeostasis are still lacking.

Due to the lack of evidence concerning the role of auxin homeostasis during seed development, we attempted to analyse the expression patterns of $A t G H 3$ group II family gene members because of their crucial role in auxin homeostasis. Based on the data collected from the Arabidopsis eFP browser [97] and phylogenetic analyses of those proteins (Figure 2a,b; Supplementary Table S1; Supplemental data S2), it is apparent that these AtGH3 homologous genes are differentially expressed during seed development. Most $A t G H 3$ genes, which could be divided into different clades (Figure 2a), appeared to be highly expressed during the late stages of seed development, except that AtGH3.5 displays a more stable and abundant expression pattern throughout all stages of seed development 
(Figure 2b). Interestingly, some GH3 genes having a closer phylogenetic relationship exhibit similar expression patterns during seed development (Figure 2a,b). For example, the AtGH3.14 and AtGH3.15 as well as the $A t G H 3.2$ and $A t G H 3.4$ gene pair shows higher levels of expression at the late stages of seed development than do other AtGH3 members (Figure 2b). By contrast, other GH3 genes with close evolutionary relationships, such as AtGH3.18 and AtGH3.19, AtGH3.7 and AtGH3.12, and AtGH3.5 and AtGH3.6, show divergent expression patterns during seed development (Figure 2a,b). Furthermore, AtGH3.6, AtGH3.13, AtGH3.16, and AtGH3.17, which are divided into different evolutionary subclades (Figure 2a), are expressed at very low expression levels in seed development. Notably, although AtGH3.3 and $A t G H 3.18$ are grouped into different clades (Figure 2a), both of them were highly expressed at both the early and late stages of seed development (Figure 2a,b). In contrast, AtGH3.9 was specifically expressed at high levels in the middle stages of seed development. These results indicate that GH3 family gene-mediated auxin homeostasis might regulate seed development. More effort is needed to develop imaging approaches and decipher the molecular regulatory mechanism of auxin homeostasis regulation of seed development.

(a)

(b)

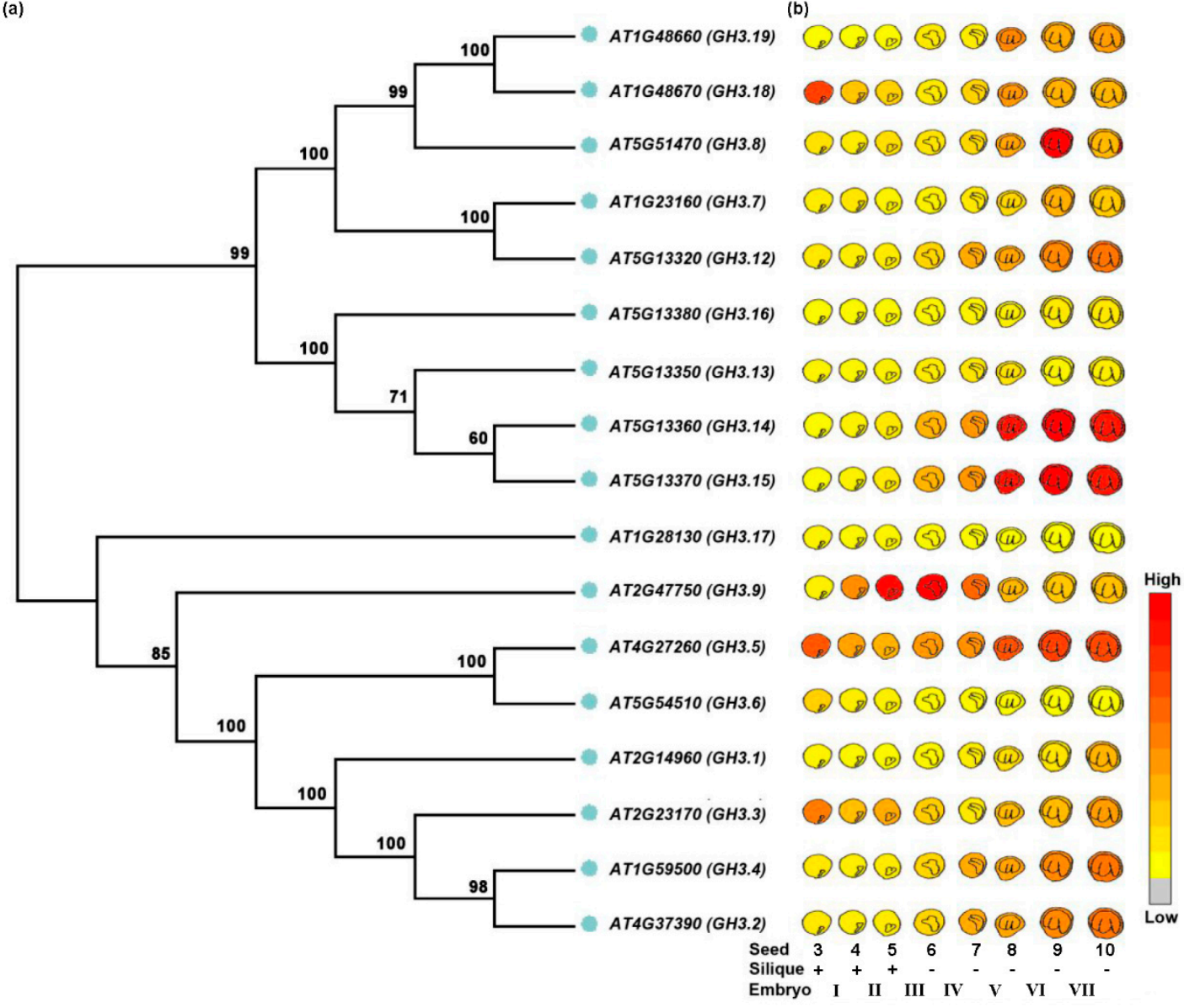

Figure 2. GH3 sub-family genes involved in seed development in Arabidopsis thaliana. (a) Phylogenetic tree of the 17 Arabidopsis GH3 group II proteins. The tree was constructed using MEGA7.0 program by Neighbor Joining (NJ) clustering method. Bootstrap numbers (1000 replicates) are presented for all branches. (b) The expression pattern of Arabidopsis GH3 group II genes during seed development. Data was collected from Arabidopsis eFP browser (http://bar.utoronto.ca/efp/cgi-bin/efpWeb.cgi? primaryGene). The experimental design can be downloaded from TAIR (The Arabidopsis Information Resource). Legend: I, globular; II, heart; III, torpedo; IV, walking-stick; V, VI, curled cotyledons; VII, green cotyledons. 


\section{Auxin Is a Main Factor Influencing Seed Size and Seed Weight of Crop Species}

Seed development determines seed size and seed weight, which are the main traits of grain yields of crops. Due to the essential role of auxin in seed development, it is conceivable that auxin also functions as a key player in seed size and weight. Indeed, recent studies have shown that some auxin signaling components or genes regulated by the auxin signaling pathway can alter seed size and/or seed weight. For instance, ARF6 and ARF8, which are partially controlled by microR167, appear to be required for seed size in Camelina [98]. Big Grain 1 (BG1), which is a plasma membrane-associated protein involved in auxin transport and the auxin response, has the potential to improve both grain size and weight in rice [99]. Another QTL, qTGW3 (QTL FOR THOUSAND-GRAIN WEIGHT ON CHROMOSOME 3), encoding the GSK3/SHAGGY-Like Kinase OsGSK5/OsSK41, negatively controls grain size and weight in rice by interacting with and phosphorylating OsARF4 [100], suggesting an important role of qTGW3 in auxin-regulated seed production. In Brassica napus L., ARF18 has been identified based on forward genetics and has been confirmed to function in determining final seed weight by regulating the classic auxin signaling pathway during silique development [10]. In addition, some regulators associated with the auxin-mediated determination of seed size have also been identified. For instance, SMOS1 (SMALL ORGAN SIZE 1) encodes an auxin-regulated APETAL2-type transcription factor and is positively regulated by OsARF1 in rice [101]. The loss of function of SMOS1 causes pleiotropic developmental phenotypes, including small seed size [101,102], suggesting a crucial role for SMOS1 in seed size regulation.

Seed development is a complex and dynamic process that is strictly regulated by multiple growth regulators. It has been shown that auxin regulates seed development synergistically or antagonistically with other plant hormones. For example, SMOS1 can interact with the GRAS transcription factor SMOS2/DLT (DWARF AND LOW-TILLERING), which positively regulates seed development via brassinosteroid (BR) signaling to modulate its transcription activity. This finding provides the first evidence that the interplay of the auxin and BR signaling pathways modulates seed size in crops. Despite limited evidence for auxin-mediated seed size and seed weight, its indispensable role as a master regulator of seed development makes auxin a potential target for improving seed size, seed weight and grain yield in crop species.

\section{Concluding Remarks: Auxin as a High Potential Target for the Optimization of Crop Yields}

Seed size and seed weight regulated by seed development are critical determinants of crop yields. An improved understanding of the molecular mechanisms and regulatory networks underlying seed development will facilitate the elucidation of the genetic basis of yield-related traits and breeding of high-yielding crop species. Auxin is essential for optimal plant development and reproduction, but its role in seed development has received relatively little attention. Greater research efforts are needed to systemically decipher the molecular mechanisms of auxin-mediated seed development, especially the regulation of auxin homeostasis maintenance during seed development. In both model plant and crop species, the identification of additional critical genes related to auxin metabolism, transport, signaling or homeostasis is a key step in understanding the role of auxin during seed development. Additionally, elucidating the crosstalk between auxin and other signaling pathways is important to better understand the regulatory network underlying auxin control of seed development.

Overall, this review has summarized the recent progress in auxin-mediated seed development, emphasizing the importance of auxin in regulating seed development and pinpointing the potential role of auxin in increasing crop yields. Fine tuning the auxin gradient and maxima may allow us to achieve desired crop performance and optimal yield. Based on the findings summarized in this review, we proposed three competitive strategies for increasing crop yields, listed here (Figure 3). (1) The first involves genetic modifications of auxin-mediated seed development. Once the auxin-related genes associated with seed traits are identified by reverse genetics or forward genetics, including QTL mapping or GWASs, combinatorial approaches for genetic modifications can be adopted. These include the overexpression and knock down (or the knockout) of the selected gene(s) and the 
specific modifications of gene expression driven by cell- or tissue-specific promoters using classic genetic methods or gene editing technology (e.g., the CRISPR/Cas9 system). (2) The second involves molecular breeding for improving auxin-mediated seed development. Molecular markers linked to the genes or QTLs controlling auxin-mediated seed development can be used to select improved plants with desired seed traits via marker-assisted breeding. (3) The third involves agronomic innovation to intervene in auxin-mediated seed development. Based on the role of auxin during seed development, exogenous applications of auxin or auxin transport inhibitors can be utilized to modulate the impact of auxin on seed development at specific stages of seed development in crops. In summary, combined with a deep understanding of the complex regulatory network underlying auxin-mediated seed development, advanced biotechnology for genetic manipulation, and appropriate agronomic innovation in a synergistic fashion, it might be anticipated that rewiring auxin homeostasis and cellular response governing seed development is a promising approach that allows us to increase crop seed production.

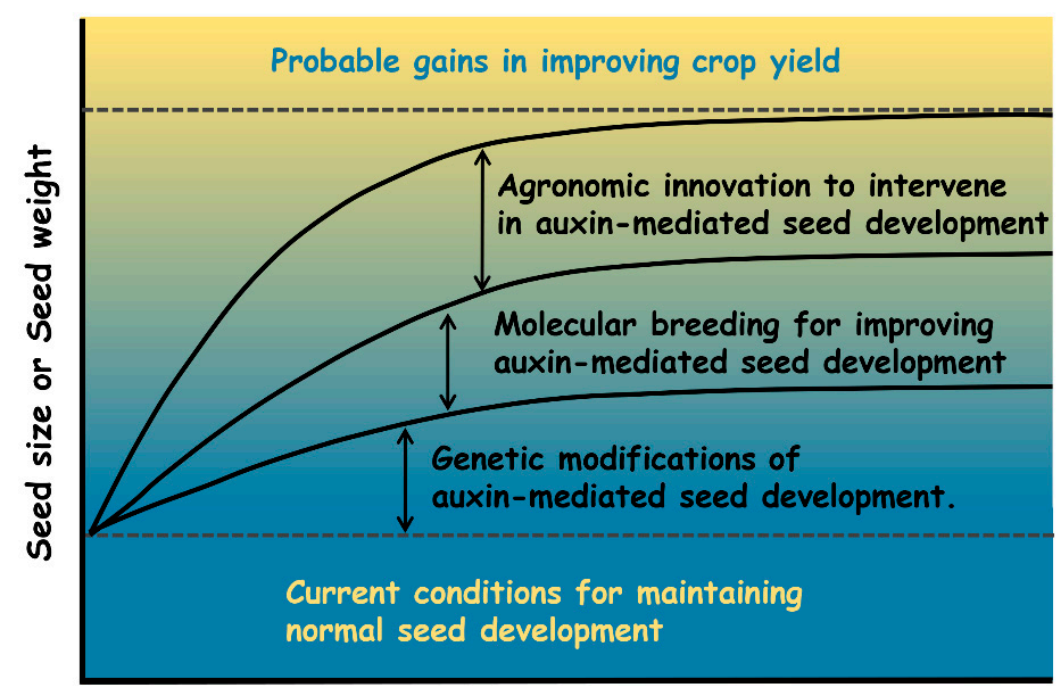

Figure 3. Potential strategies for future genetic improvement of crop yield.

Supplementary Materials: Supplementary Materials can be found at http://www.mdpi.com/1422-0067/21/5/1662/ s1.

Author Contributions: Y.W. designed the review; Y.W., J.C., G.L. and D.Q. analyzed and summarized the data; Y.W. and X.L. wrote the manuscript. All authors have read and agreed to the published version of the manuscript.

Funding: This research was funded by the National Key Research and Development Program of China (2016YFA0500503), the National Natural Science Foundation of China (31230050, 31730066), and the Huazhong Agricultural University Scientific \& Technological Self-innovation Foundation (Program No. 2015RC014).

Acknowledgments: We thank Chao Su (University of Freiburg) and April Hastwell (The University of Queensland) for helpful comments on the manuscript.

Conflicts of Interest: The authors declare no conflict of interest.

\section{References}

1. Herridge, R.; Day, R.; Baldwin, S.; Macknight, R. Rapid analysis of seed size in Arabidopsis for mutant and QTL discovery. Plant Methods 2011, 7, 3. [CrossRef] [PubMed]

2. Sundaresan, V. Control of seed size in plants. Proc. Natl. Acad. Sci. USA 2005, 102, 17887-17888. [CrossRef] [PubMed]

3. Sakuma, S.; Salomon, B.; Komatsuda, T. The domestication syndrome genes responsible for the major changes in plant form in the Triticeae crops. Plant Cell Physiol. 2011, 52, 738-749. [CrossRef] [PubMed] 
4. Scott, R.J.; Spielman, M.; Bailey, J.; Dickinson, H.G. Parent-of-origin effects on seed development in Arabidopsis thaliana. Development 1998, 125, 3329-3341. [PubMed]

5. Garcia, D.; Saingery, V.; Chambrier, P.; Mayer, U.; Jurgens, G.; Berger, F. Arabidopsis haiku mutants reveal new controls of seed size by endosperm. Plant Physiol. 2003, 131, 1661-1670. [CrossRef] [PubMed]

6. Sun, X.; Shantharaj, D.; Kang, X.; Ni, M. Transcriptional and hormonal signaling control of Arabidopsis seed development. Curr. Opin. Plant Biol. 2010, 13, 611-620. [CrossRef] [PubMed]

7. Chay, P.; Thurling, N. Identification of genes controlling pod length in spring rapeseed, Brassica napus L., and their utilization for yield improvement. Plant Breed. 1989, 103, 54-62. [CrossRef]

8. King, S.P.; John, E.L.; Robert, T.F. Carbohydrate content and enzyme metabolism in developing canola siliques. Plant Physiol. 1997, 114, 153-160. [CrossRef]

9. Bennett, E.J.; Roberts, J.A.; Wagstaff, C. The role of the pod in seed development: Strategies for manipulating yield. New Phytol. 2011, 190, 838-853. [CrossRef]

10. Liu, J.; Hua, W.; Hu, Z.; Yang, H.; Zhang, L.; Li, R.; Deng, L.; Sun, X.; Wang, X.; Wang, H. Natural variation in ARF18 gene simultaneously affects seed weight and silique length in polyploid rapeseed. Proc. Natl. Acad. Sci. USA 2015, 112, E5123-E5132. [CrossRef]

11. Fang, W.; Wang, Z.; Cui, R.; Li, J.; Li, Y. Maternal control of seed size by EOD3/CYP78A6 in Arabidopsis thaliana. Plant J. 2012, 70, 929-939. [CrossRef] [PubMed]

12. Garcia, D.; Fitz Gerald, J.N.; Berger, F. Maternal control of integument cell elongation and zygotic control of endosperm growth are coordinated to determine seed size in Arabidopsis. Plant Cell 2005, 17, 52-60. [CrossRef] [PubMed]

13. Luo, M.; Dennis, E.S.; Berger, F.; Peacock, W.J.; Chaudhury, A. MINISEED3 (MINI3), a WRKY family gene, and HAIKU2 (IKU2), a leucine-rich repeat (LRR) KINASE gene, are regulators of seed size in Arabidopsis. Proc. Natl. Acad. Sci. USA 2005, 102, 17531-17536. [CrossRef] [PubMed]

14. Ohto, M.-A.; Fischer, R.L.; Goldberg, R.B.; Nakamura, K.; Harada, J.J. Control of seed mass by APETALA2. Proc. Natl. Acad. Sci. USA 2005, 10, 3123-3128. [CrossRef]

15. Schruff, M.C.; Spielman, M.; Tiwari, S.; Adams, S.; Fenby, N.; Scott, R.J. The Auxin Response Factor 2 gene of Arabidopsis links auxin signalling, cell division, and the size of seeds and other organs. Development 2006, 133, 251-261. [CrossRef]

16. Adamski, N.M.; Anastasiou, E.; Eriksson, S.; O'Neill, C.M.; Lenhard, M. Local maternal control of seed size by KLUH/CYP78A5-dependent growth signaling. Proc. Natl. Acad. Sci. USA 2009, 106, 20115-20120. [CrossRef]

17. Zhou, Y.; Zhang, X.; Kang, X.; Zhao, X.; Zhang, X.; Ni, M. Short Hypocotyl Under Blue1 associates with Miniseed 3 and Haiku2 promoters in vivo to regulate Arabidopsis seed development. Plant Cell 2009, 21, 106-117. [CrossRef]

18. Wang, A.; Garcia, D.; Zhang, H.; Feng, K.; Chaudhury, A.; Berger, F.; Peacock, W.J.; Dennis, E.S.; Luo, M. The VQ motif protein IKU1 regulates endosperm growth and seed size in Arabidopsis. Plant J. 2010, 63, 670-679. [CrossRef]

19. Kang, X.; Li, W.; Zhou, Y.; Ni, M. A WRKY transcription factor recruits the SYG1-like protein SHB1 to activate gene expression and seed cavity enlargement. PLoS Genet. 2013, 9, e1003347. [CrossRef]

20. Kang, X.; Ni, M. Arabidopsis Short Hypocotyl under Blue1 contains SPX and EXS domains and acts in cryptochrome signaling. Plant Cell 2006, 18, 921-934. [CrossRef]

21. Morinaka, Y.; Sakamoto, T.; Inukai, Y.; Agetsuma, M.; Kitano, H.; Ashikari, M.; Matsuoka, M. Morphological alteration caused by brassinosteroid insensitivity increases the biomass and grain production of rice. Plant Physiol. 2006, 141, 924-931. [CrossRef] [PubMed]

22. Riefler, M.; Novak, O.; Strnad, M.; Schmulling, T. Arabidopsis cytokinin receptor mutants reveal functions in shoot growth, leaf senescence, seed size, germination, root development, and cytokinin metabolism. Plant Cell 2006, 18, 40-54. [CrossRef] [PubMed]

23. Roxrud, I.; Lid, S.E.; Fletcher, J.C.; Schmidt, E.D.; Opsahl-Sorteberg, H.G. GASA4, one of the 14-member Arabidopsis GASA family of small polypeptides, regulates flowering and seed development. Plant Cell Physiol. 2007, 48, 471-483. [CrossRef] [PubMed]

24. Jiang, W.B.; Huang, H.Y.; Hu, Y.W.; Zhu, S.W.; Wang, Z.Y.; Lin, W.H. Brassinosteroid regulates seed size and shape in Arabidopsis. Plant Physiol. 2013, 162, 1965-1977. [CrossRef] 
25. Xia, T.; Li, N.; Dumenil, J.; Li, J.; Kamenski, A.; Bevan, M.W.; Gao, F.; Li, Y. The ubiquitin receptor DA1 interacts with the E3 ubiquitin ligase DA2 to regulate seed and organ size in Arabidopsis. Plant Cell 2013, 25, 3347-3359. [CrossRef]

26. Du, L.; Li, N.; Chen, L.; Xu, Y.; Li, Y.; Zhang, Y.; Li, C.; Li, Y. The ubiquitin receptor DA1 regulates seed and organ size by modulating the stability of the ubiquitin-specific protease UBP15/SOD2 in Arabidopsis. Plant Cell 2014, 26, 665-677. [CrossRef]

27. Zhang, Y.; Du, L.; Xu, R.; Cui, R.; Hao, J.; Sun, C.; Li, Y. Transcription factors SOD7/NGAL2 and DPA4/NGAL3 act redundantly to regulate seed size by directly repressing KLU expression in Arabidopsis thaliana. Plant Cell 2015, 27, 620-632. [CrossRef]

28. Zhao, J.; Bai, W.; Zeng, Q.; Song, S.; Zhang, M.; Li, X.; Hou, L.; Xiao, Y.; Luo, M.; Li, D.; et al. Moderately enhancing cytokinin level by down-regulation of GhCKX expression in cotton concurrently increases fiber and seed yield. Mol. Breed. 2015, 35, 60. [CrossRef]

29. Zhu, X.; Liang, W.; Cui, X.; Chen, M.; Yin, C.; Luo, Z.; Zhu, J.; Lucas, W.J.; Wang, Z.; Zhang, D. Brassinosteroids promote development of rice pollen grains and seeds by triggering expression of carbon starved anther, a MYB domain protein. Plant J. 2015, 82, 570-581. [CrossRef]

30. Xiao, Y.G.; Sun, Q.B.; Kang, X.J.; Chen, C.B.; Ni, M. Short Hypocotyl under Blue1 or HAIKU2 mixepression alters canola and Arabidopsis seed development. New Phytol. 2016, 209, 636-649. [CrossRef]

31. Li, N.; Xu, R.; Li, Y. Molecular networks of seed size control in plants. Annu. Rev. Plant Biol. 2019, 70, 435-463. [CrossRef] [PubMed]

32. Gustafson, F.G. Inducement of fruit development by growth promoting chemicals. Proc. Natl. Acad. Sci. USA 1936, 22, 628-636. [CrossRef] [PubMed]

33. Bernardi, J.; Lanubile, A.; Li, Q.B.; Kumar, D.; Kladnik, A.; Cook, S.D.; Ross, J.J.; Marocco, A.; Chourey, P.S. Impaired auxin biosynthesis in the defective endosperm 18 mutant is due to mutational loss of expression in the ZmYuc1 gene encoding endosperm-specific YUCCA1 protein in maize. Plant Physiol. 2012, 160, 1318-1328. [CrossRef]

34. Lur, H.-S.; Setter, T.L. Role of auxin in maize endosperm development. Plant Physiol. 1993, 103, $273-280$. [CrossRef] [PubMed]

35. Locascio, A.; Roig-Villanova, I.; Bernardi, J.; Varotto, S. Current perspectives on the hormonal control of seed development in Arabidopsis and maize: A focus on auxin. Front. Plant Sci. 2014, 5, 412. [CrossRef] [PubMed]

36. Ni, D.A.; Wang, L.J.; Ding, C.H.; Xu, Z.H. Auxin distribution and transport during embryogenesis and seed germination of Arabidopsis. Cell Res. 2001, 11, 273-278. [CrossRef]

37. Uchiumi, T.; Okamoto, T. Rice fruit development is associated with an increased IAA content in pollinated ovaries. Planta 2010, 232, 579-592. [CrossRef]

38. Chen, Y.; Liu, L.; Shen, Y.; Liu, S.J.; Huang, J.X.; Long, Q.Z.; Wu, W.; Yang, C.Y.; Chen, H.; Guo, X.P.; et al. Loss of function of the cytochrome P450 gene CYP78B5 causes giant embryos in rice. Plant Mol. Biol. Rep. 2015, 33, 69-83. [CrossRef]

39. Forestan, C.; Meda, S.; Varotto, S. ZmPIN1-mediated auxin transport is related to cellular differentiation during maize embryogenesis and endosperm development. Plant Physiol. 2010, 152, 1373-1390. [CrossRef]

40. Figueiredo, D.D.; Batista, R.A.; Roszak, P.J.; Köhler, C. Auxin production couples endosperm development to fertilization. Nat. Plants 2015, 1, 15184. [CrossRef]

41. Batista, R.A.; Figueiredo, D.D.; Santos-Gonzalez, J.; Kohler, C. Auxin regulates endosperm cellularization in Arabidopsis. Genes Dev. 2019, 33, 466-476. [CrossRef]

42. Figueiredo, D.D.; Batista, R.A.; Roszak, P.J.; Hennig, L.; Köhler, C. Auxin production in the endosperm drives seed coat development in Arabidopsis. ELife 2016, 5, e20542. [CrossRef] [PubMed]

43. Tivendale, N.D.; Davidson, S.E.; Davies, N.W.; Smith, J.A.; Dalmais, M.; Bendahmane, A.I.; Quittenden, L.J.; Sutton, L.; Bala, R.K.; Le Signor, C.; et al. Biosynthesis of the halogenated auxin, 4-chloroindole-3-acetic acid. Plant Physiol. 2012, 159, 1055-1063. [CrossRef] [PubMed]

44. Mashiguchi, K.; Tanaka, K.; Sakai, T.; Sugawara, S.; Kawaide, H.; Natsume, M.; Hanada, A.; Yaeno, T.; Shirasu, K.; Yao, H.; et al. The main auxin biosynthesis pathway in Arabidopsis. Proc. Natl. Acad. Sci. USA 2011, 108, 18512-18517. [CrossRef] [PubMed] 
45. Stepanova, A.N.; Yun, J.; Robles, L.M.; Novak, O.; He, W.; Guo, H.; Ljung, K.; Alonso, J.M. The Arabidopsis YUCCA1 flavin monooxygenase functions in the indole-3-pyruvic acid branch of auxin biosynthesis. Plant Cell 2011, 23, 3961-3973. [CrossRef]

46. Won, C.; Shen, X.; Mashiguchi, K.; Zheng, Z.; Dai, X.; Cheng, Y.; Kasahara, H.; Kamiya, Y.; Chory, J.; Zhao, Y. Coversion of tryptophan to indole-3-acetic acid by Tryptophan of Arabidopsis and Yuccas in Arabidopsis. Proc. Natl. Acad. Sci. USA 2011, 108, 18518-18523. [CrossRef]

47. Cheng, Y.; Dai, X.; Zhao, Y. Auxin synthesized by the YUCCA flavin monooxygenases is essential for embryogenesis and leaf formation in Arabidopsis. Plant Cell 2007, 19, 2430-2439. [CrossRef]

48. McAdam, E.L.; Meitzel, T.; Quittenden, L.J.; Davidson, S.E.; Dalmais, M.; Bendahmane, A.I.; Thompson, R.; Smith, J.J.; Nichols, D.S.; Urquhart, S.; et al. Evidence that auxin is required for normal seed size and starch synthesis in Pea. New Phytol. 2017, 216, 193-204. [CrossRef]

49. Robert, H.S.; Park, C.; Gutièrrez, C.L.; Wójcikowska, B.; Pěnčík, A.; Novák, O.; Chen, J.; Grunewald, W.; Dresselhaus, T.; Friml, J.; et al. Maternal auxin supply contributes to early embryo patterning in Arabidopsis. Nat. Plants 2018, 4, 548-553. [CrossRef]

50. Bernardi, J.; Battaglia, R.; Bagnaresi, P.; Lucini, L.; Marocco, A. Transcriptomic and metabolomic analysis of ZmYUC1 mutant reveals the role of auxin during early endosperm formation in maize. Plant Sci. 2019, 281, 133-145. [CrossRef]

51. Shi, L.L.; Song, J.R.; Guo, C.C.; Wang, B.; Guan, Z.L.; Yang, P.; Chen, X.; Zhang, Q.H.; King, G.J.; Wang, J.; et al. A CACTA-like transposable element in the upstream region of BnaA9.CYP78A9 acts as an enhancer to increase silique length and seed weight in rapeseed. Plant J. 2019, 98, 524-539. [CrossRef]

52. Stone, S.L.; Braybrook, S.A.; Paula, S.L.; Kwong, L.W.; Meuser, J.; Pelletier, J.; Hsieh, T.F.; Fischer, R.L.; Goldberg, R.B.; Harada, J.J. Arabidopsis LEAFY COTYLEDON2 induces maturation traits and auxin activity: Implications for somatic embryogenesis. Proc. Natl. Acad. Sci. USA 2008, 105, 3151-3156. [CrossRef]

53. Wójcikowska, B.; Jaskola, K.; Gasiorek, P.; Meus, M.; Nowak, K.; Gaj, M.D. Leafy Cotyledon2 (LEC2) promotes embryogenic induction in somatic tissues of Arabidopsis, via YUCCA-mediated auxin biosynthesis. Planta 2013, 238, 425-440. [CrossRef]

54. Yin, L.L.; Xue, H.W. The MADS29 transcription factor regulates the degradation of the nucellus and the nucellar projection during rice seed development. Plant Cell 2012, 24, 1049-1065. [CrossRef]

55. Koltunow, A.M.; Grossniklaus, U. Apomixis: A developmental perspective. Annu. Rev. Plant Biol. 2003, 54, 547-574. [CrossRef]

56. Nitsch, J.P. Growth and morphogenesis of the Strawberry as related to auxin. Am. J. Bot. 1950, 37, $211-215$. [CrossRef]

57. Sailer, C.; Schmid, B.; Grossniklaus, U. Apomixis allows the transgenerational fixation of phenotypes in hybrid plants. Curr. Biol. 2016, 26, 331-337. [CrossRef]

58. Figueiredo, D.D.; Köhler, C. Auxin: A molecular trigger of seed development. Genes Dev. 2018, 32, 479-490. [CrossRef]

59. Carraro, N.; Forestan, C.; Canova, S.; Traas, J.; Varotto, S. ZmPIN1a and ZmPIN1b encode two novel putative candidates for polar auxin transport and plant architecture determination of maize. Plant Physiol. 2006, 142, 254-264. [CrossRef]

60. Robert, H.S.; Grunewald, W.; Sauer, M.; Cannoot, B.; Soriano, M.; Swarup, R.; Weijers, D.; Bennett, M.; Boutilier, K.; Friml, J. Plant embryogenesis requires AUX/LAX-mediated auxin influx. Development 2015, 142, 702-711. [CrossRef]

61. Petrášek, J.; Mravec, J.; Bouchard, R.; Blakeslee, J.J.; Abas, M.; Seifertová, D.; Wiśniewska, J.; Tadele, Z.; Kubeš, M.; Čovanová, M.; et al. PIN proteins perform a rate-limiting function in cellular auxin efflux. Science 2006, 312, 914-918. [CrossRef] [PubMed]

62. Friml, J.; Vieten, A.; Sauer, M.; Weijers, D.; Schwarz, H.; Hamann, T.; Offringa, R.; Jürgens, G. Efflux-dependent auxin gradients establish the apical-basal axis of Arabidopsis. Nature 2003, 426, 147-153. [CrossRef] [PubMed]

63. De Smet, I.; Jürgens, G. Patterning the axis in plants-auxin in control. Curr. Opin. Genet. Dev. 2007, 17, 337-343. [CrossRef] [PubMed]

64. Fischer, C.; Neuhaus, G. Influence of auxin on the establishment of bilateral symmetry in monocots. Plant J. 1996, 9, 659-669. [CrossRef]

65. Fischer-Iglesias, C.; Sundberg, B.; Neuhaus, G.; Jones, A. Auxin distribution and transport during embryonic pattern formation in wheat. Plant J. 2001, 26, 115-129. [CrossRef] 
66. Forestan, C.; Farinati, S.; Varotto, S. The maize PIN gene family of auxin transporters. Front. Plant Sci. 2012, 3, 16. [CrossRef]

67. Noguero, M.; Signor, C.L.; Vernound, V.; Bandyopadhyay, K.; Sanchez, M.; Fu, C.X.; Torres-Jerez, I.; Wen, J.Q.; Mysore, K.S.; Gallardo, K.; et al. DASH transcription factor impacts Medicago truncatula seed size by its action on embryo morphogenesis and auxin homeostasis. Plant J. 2015, 81, 453-466. [CrossRef]

68. Bennett, M.J.; Marchant, A.; Green, H.G.; May, S.T.; Ward, S.P.; Millner, P.A.; Walker, A.R.; Schulz, B.; Feldmann, K.A. Arabidopsis AUX1 gene: A permease-like regulator of root gravitropism. Science 1996, 273, 948-950. [CrossRef]

69. Yang, Y.; Hammes, U.Z.; Taylor, C.G.; Schachtman, D.P.; Nielsen, E. High-affinity auxin transporter by the aux1 influx carrier protein. Curr. Biol. 2006, 16, 1123-1127. [CrossRef]

70. Parry, G.; Marchant, A.; May, S. Quick on the uptake: Characterization of a family of plant auxin influx carriers. J. Plant Growth Regul. 2001, 20, 217-225. [CrossRef]

71. Ugartechea-Chirino, Y.; Swarup, R.; Swarup, K.; Péret, B.; Whitworth, M.; Bennett, M.J.; Bougourd, S. The AUX LAX family of auxin influx carriers is required for the establishment of embryonic root cell organization in Arabidopsis thaliana. Ann. Bot. 2010, 105, 277-289. [CrossRef]

72. Tiwari, S.B.; Wang, X.-J.; Hagen, G.; Guifoyle, T.J. AUX/IAA proteins are active repressors, and their stability and activity are modulated by auxin. Plant Cell 2001, 13, 2809-2822. [CrossRef]

73. Ulmasov, T.; Hagen, G.; Guilfoyle, T.J. ARF1, a transcription factor that binds to auxin response elements. Science 1997, 276, 1865-1868. [CrossRef]

74. Dharmasiri, N.; Dharmasiri, S.; Weijers, D.; Lechner, E.; Yamada, M.; Hobbie, L.; Ehrismann, J.S.; Jurgens, G.; Estelle, M. Plant development is regulated by a family of auxin receptor F box proteins. Dev. Cell 2005, 9, 109-119. [CrossRef]

75. Kepinski, S.; Leyser, O. The Arabidopsis F-box protein TIR1 is an auxin receptor. Nature 2005, 435, $446-451$. [CrossRef]

76. Ulmasov, T.; Hagen, G.; Guilfoyle, T.J. Activation and repression of transcription by auxin-response factors. Proc. Natl. Acad. Sci. USA 1999, 11, 5844-5849. [CrossRef]

77. Abel, S.; Theologis, A. Early genes and auxin action. Plant Physiol. 1996, 111, 9-17. [CrossRef]

78. Hamann, T.; Benkova, E.; Bäurele, I.; Kientz, M.; Jürgens, G. The Arabidopsis Bodenlos gene encodes an auxin response protein inhibiting MONOPTEROS-mediated embryo patterning. Genes Dev. 2002, 16, 1610-1615. [CrossRef]

79. Ploense, S.E.; Wu, M.-F.; Nagpal, P.; Reed, J.W. A gain-of-function mutation in IAA18 alters Arabidopsis embryonic apical patterning. Development 2009, 136, 1509-1517. [CrossRef]

80. Berleth, T.; Jürgens, G. The role of the monopteros gene in organising the basal body region of the Arabidopsis embryo. Development 1993, 118, 575-587.

81. Hardtke, C.; Berleth, T. The Arabidopsis gene MONOPTEROS encodes a transcription factor mediating embryo axis formation and vascular development. EMBO J. 1998, 17, 1405-1411. [CrossRef] [PubMed]

82. Okushima, Y.; Overvoorde, P.J.; Arima, K.; Alonso, J.M.; Chan, A.; Chang, C.; Ecker, J.R.; Hughes, B.; Lui, A.; Nguyen, D.; et al. Functional genomic analysis of the AUXIN RESPONSE FACTOR gene family members in Arabidopsis thaliana: Unique and overlapping functions of ARF7 and ARF19. Plant Cell 2005, 17, 444-463. [CrossRef]

83. Goetz, M.; Vivian-Smith, A.; Johnson, S.D.; Koltunow, A.M. AUXIN RESPONSE FACTOR8 is a negative regulator of fruit initiation in Arabidopsis. Plant Cell 2006, 18, 1873-1886. [CrossRef] [PubMed]

84. Wu, M.F.; Tian, Q.; Reed, J.W. Arabidopsis microRNA167 controls patterns of ARF6 and ARF8 expression, and regulates both female and male reproduction. Development 2006, 133, 4211-4218. [CrossRef] [PubMed]

85. Yao, X.; Chen, J.; Zhou, J.; Yu, H.; Ge, C.; Zhang, M.; Gao, X.; Dai, X.; Yang, Z.N.; Zhao, Y. An essential role for miRNA167 in maternal control of embryonic and seed development. Plant Physiol. 2019, 180, 453-464. [CrossRef] [PubMed]

86. Xing, H.; Pudake, R.N.; Guo, G.; Xing, G.; Hu, Z.; Zhang, Y.; Sun, Q.; Ni, Z. Genome-wide identification and expression profiling of auxin response factor (ARF) gene family in maize. BMC Genomics 2011, 12, 178. [CrossRef]

87. Kelley, D.R.; Arreola, A.; Gallagher, T.L.; Gasser, C.S. ETTIN (ARF3) physically interacts with KANADI proteins to form a functional complex essential for integument development and polarity determination in Arabidopsis. Development 2012, 139, 1105-1109. [CrossRef] 
88. Zhu, Q.; Li, B.Y.; Mu, S.Y.; Han, B.; Cui, R.Z.; Xu, M.Y.; You, Z.Z.; Dong, H.S. TTG2-regulated development is related to expression of putative AUXIN RESPONSE FACTOR genes in tobacco. BMC Genomics 2013, 14, 806. [CrossRef]

89. Ge, J.; Li, B.; Shen, D.; Xie, J.; Long, J.; Dong, H. Tobacco TTG2 regulates vegetative growth and seed production via the predominant role of ARF8 in cooperation with ARF17 and ARF19. BMC Plant Biol. 2016, 16, 126. [CrossRef]

90. Teale, W.D.; Paponov, I.A.; Palme, K. Auxin in action: Signalling, transport and the control of plant growth and development. Nat. Rev. Mol. Cell Biol. 2006, 7, 847-859. [CrossRef]

91. Stepanova, A.N.; Alonso, J.M. Cutting out the middle man in light-hormone interactions. Dev Cell 2016, 39, 524-526. [CrossRef] [PubMed]

92. Vanneste, S.; Friml, J. Auxin: A trigger for change in plant development. Cell 2009, 136, 1005-1016. [CrossRef] [PubMed]

93. Normanly, J. Approaching cellular and molecular resolution of auxin biosynthesis and metabolism. Cold Spring Harb. Perspect. Biol. 2010, 2, a001594. [CrossRef]

94. Rosquete, M.R.; Barbez, E.; Kleine-Vehn, J. Cellular auxin homeostasis: Gatekeeping is housekeeping. Mol. Plant 2011, 5, 772-786. [CrossRef] [PubMed]

95. Ljung, K. Auxin metabolism and homeostasis during plant development. Development 2013, 140, $943-950$. [CrossRef]

96. Ishimaru, K.; Hirotsu, N.; Madoka, Y.; Murakami, N.; Hara, N.; Onodera, H.; Kashiwagi, T.; Ujiie, K.; Shimizu, B.; Onishi, A.; et al. Loss of function of the IAA-glucose hydrolase gene TGW6 enhances rice grain weight and increases yield. Nat. Genet. 2013, 45, 707-711. [CrossRef] [PubMed]

97. Schmid, M.; Davison, T.S.; Henz, S.R.; Pape, U.J.; Demar, M.; Vingron, M.; Schölkopf, B.; Weigel, D.; Lohmann, J.U. A gene expression map of Arabidopsis thaliana development. Nat. Genet. 2005, 37, 501-506. [CrossRef] [PubMed]

98. Na, G.; Mu, X.; Grabowski, P.; Schmutz, J.; Lu, C. Enhancing microRNA167A expression in seed decreases the alpha-linolenic acid content and increases seed size in Camelina sativa. Plant J. 2019, 98, 346-358. [CrossRef]

99. Liu, L.C.; Tong, H.N.; Xiao, Y.H.; Che, R.H.; Xu, F.; Hu, B.; Liang, C.Z.; Chu, J.F.; Li, J.Y.; Chu, C.C. Activation of Big Grain1 significantly improves grain size by regulating auxin transport in rice. Proc. Natl. Acad. Sci. USA 2015, 112, 11102-11107. [CrossRef]

100. Hu, Z.; Lu, S.J.; Wang, M.J.; He, H.; Sun, L.; Wang, H.; Liu, X.H.; Jiang, L.; Sun, J.L.; Xin, X.; et al. A novel QTL qTGW3 encodes the GSK3/SHAGGY-Like kinase OsGSK5/OsSK41 that interacts with OsARF4 to negatively regulate grain size and weight in rice. Mol. Plant 2018, 11, 736-749. [CrossRef]

101. Aya, K.; Hobo, T.; Sato-Izawa, K.; Ueguchi-Tanaka, M.; Kitano, H.; Matsuoka, M. A novel AP2-type transcription factor, Small Organ Size1, controls organ size downstream of an auxin signaling pathway. Plant Cell Physiol. 2014, 55, 897-912. [CrossRef] [PubMed]

102. Hirano, K.; Yoshida, H.; Aya, K.; Kawamura, M.; Hayashi, M.; Hobo, T.; Sato-Izawa, K.; Kitano, H.; Ueguchi-Tanaka, M.; Matsuoka, M. SMALL ORGAN SIZE 1 and SMALL ORGAN SIZE 2/DWARF AND LOW-TILLERING form a complex to integrate auxin and brassinosteroid signaling in rice. Mol. Plant 2017, 10, 590-604. [CrossRef] [PubMed]

(C) 2020 by the authors. Licensee MDPI, Basel, Switzerland. This article is an open access article distributed under the terms and conditions of the Creative Commons Attribution (CC BY) license (http://creativecommons.org/licenses/by/4.0/). 